\title{
Reduction of Iron Oxide Contained in Molten Slags with Solid Carbon*
}

\author{
By Masayasu SUGATA, ${ }^{* *}$ Takashi SUGIYAMA, ${ }^{* * *}$ and Shin-ichi KONDO***
}

\begin{abstract}
Synopsis
The reduction rate of iron oxide contained in molten slags by rotating carbon rod or coke rod was measured. The range of temperature was from $1350^{\circ}$ to $1450^{\circ} \mathrm{C}$ and of iron oxide concentration is from 5 to $90 \%$. At the higher revolution speed of a rod, it has no effect on the reduction rate. Thus, in this range, the rate-determining step can be best interpreted to be at the chemical reaction and the reduction rate is proportional to the first order of the estimated activity of iron oxide contained in slags. The obtained rate equation is;

$$
-\frac{1}{A} \dot{n}_{\mathrm{FeO}}=17.3 \exp \left(-\frac{39700}{R T}\right) \times a_{\mathrm{FeO}}
$$

Since " FeO" activity is generally not known at every temperature, a practical rate equation is set $u p$, in which the activity of " $\mathrm{FeO}$ " at $1600^{\circ} \mathrm{C}$ obtained by Samarin and Schvartsman was used.

The bubbles cover a part of the reaction surface and suppress the reaction in the case of its slow generating rate, but break the laminar film on the rod and accelerate the reaction rate in the case of its fast generating rate. Foaming of the slag vigorously occurs in a certain range of the slag composition with high viscosity and surface tension.
\end{abstract}

\section{Introduction}

A large number of studies have been carried out on the rate and mechanism of reduction of solid iron oxide with reducing gas. However a little studies on the reduction of iron oxide contained in molten slag have been made because of its experimental difficulty.

The reduction kinetics of iron oxide contained in molton slags has been reviewed by Mori.1) In addition to the reports reviewed, Krainer et al. ${ }^{2)}$ examined the rate of reduction of " $\mathrm{FeO}$ " in $\mathrm{FeO}-\mathrm{SiO}_{2}, \mathrm{FeO}$ $\mathrm{SiO}_{2}-\mathrm{CaO}$ and $\mathrm{FeO}-\mathrm{SiO}_{2}-\mathrm{CaO}-\mathrm{Al}_{2} \mathrm{O}_{3}$ slags with graphite or coke crucible using thermobalance in the range of $1200^{\circ}$ to $1500^{\circ} \mathrm{C}$. It has been concluded from the investigation that the reduction of "FeO" in molten $2 \mathrm{FeO}-\mathrm{SiO}_{2}$ system at $1400^{\circ} \mathrm{C}$ was a first order reaction with respect to $\mathrm{FeO}$ concentration, and its reaction rate constant was 3.1 to $3.4 \times 10^{-6}$ $\mathrm{mol} \mathrm{FeO} / \mathrm{cm}^{2} \cdot \mathrm{sec}$ with graphite crucible and 3.2 to $3.6 \times 10^{-6} \mathrm{~mol} \mathrm{FeO} / \mathrm{cm}^{2} \cdot \mathrm{sec}$ with coke crucible. The value of activation energy is $27 \mathrm{kcal} / \mathrm{mol}$.

Philbrook and Kirkbride ${ }^{3)}$ have been examined the reduction of molten slag $(100 \mathrm{~g}$ ) with $300 \mathrm{~g}$ of carbon saturated iron in graphite crucible of $48 \mathrm{~mm}$ inside diameter and $140 \mathrm{~mm}$ deep. They have estimated that the reaction rate was proportional to the square of $\mathrm{FeO}$ concentration and obtained that the value of the reaction rate constant between slag and graphite was $1.2 \times 10^{-4} \mathrm{~g}-\mathrm{FeO} / \mathrm{cm}^{2} \cdot \mathrm{min}$ and the activation energy was $10 \mathrm{kcal} / \mathrm{mol}$. Shabrin ${ }^{4}$ melted FeO-contained slag in an alumina crucible and put a $15 \mathrm{~mm} \phi$ graphite ball into it, and obtained the rate of $\mathrm{FeO}$ reduction by the generated gas. The experimental slag composition was 5.3 to $19.6 \% \mathrm{FeO}, 31.3$ to $38.8 \% \mathrm{CaO}$, 34.7 to $42.0 \% \mathrm{SiO}_{2}, 8.8$ to $14.0 \% \mathrm{Al}_{2} \mathrm{O}_{3}$, and 0 to $5.0 \% \mathrm{MgO}$. They have calculated their experimental data as a second order reaction with respect to $\mathrm{FeO}$ concentration, and obtained the activation energy of 40 to $50 \mathrm{kcal} / \mathrm{mol}$.

Tarby and Philbrook ${ }^{5)}$ have studied on FeO reduction with graphite crucible. They reported that the reaction order was second order at the initial stage and then pseudo-first order at the following stage. They concluded that the primary reaction was considerably affected by the stirring of slag caused by $\mathrm{CO}$ gas, and that the difference in the reaction rate might result from the activity of " $\mathrm{FeO}$ " in a slag.

Summarizing the above mentioned experiments, the reaction rate was generally discussed in the range of low FeO content, but not in the range of high $\mathrm{FeO}$ content. Therefore, the experiments in relatively high $\mathrm{FeO}$ content were planned, and their results are reported in this paper.

\section{Experimental Method}

\section{Apparatus}

The apparatus used for the present experiments is shown in Fig. 1. The crucible (10) was made of pure iron. Slag sample (4) was heated in the pure iron crucible with a high frequency induction coil. Temperature of slag was measured by a 6 to $30 \mathrm{Rh}-\mathrm{Pt}$ thermocouple (5) which was covered with pure iron cap (8), and controlled within the range of $10^{\circ} \mathrm{C}$. The molten slag was reduced by a rotating carbon rod (13), whose diameter was 1.2 or $2.0 \mathrm{~mm}$. From the experimental results, there was no difference of reduction rate per unit surface area between both rods under a revolutional speed more than a certain value, therefore $2.0 \mathrm{~mm}$ diameter carbon rod was used in most of the experiments.

\section{Experimental Procedure}

After the sample melted and reached to the required temperature, the carbon rod was dipped in the slag and its lower surface was placed at $10 \mathrm{~mm}$ from the bottom of the crucible. The amount of slag was about $300 \mathrm{~g}$. Inside of the whole apparatus was filled with argon of 3 to $4 \mathrm{l} / \mathrm{min}$. The sample could be observed through a prism at the top of the apparatus. The heating rate of sample was about $10^{\circ} \mathrm{C} / \mathrm{min}$.

After the carbon rod was inserted into the molten

* Originally published in Tetsu-to-Hagané, 58 (1972), 1363, in Japanese. English version received July 16, 1973.

** Kimitsu Works, Nippon Steel Corp., Hitomi, Kimitsu 299-11.

*** Fundamental Research Laboratory, Nippon Steel Corp., Ida, Nakahara-ku, Kawasaki 211. 


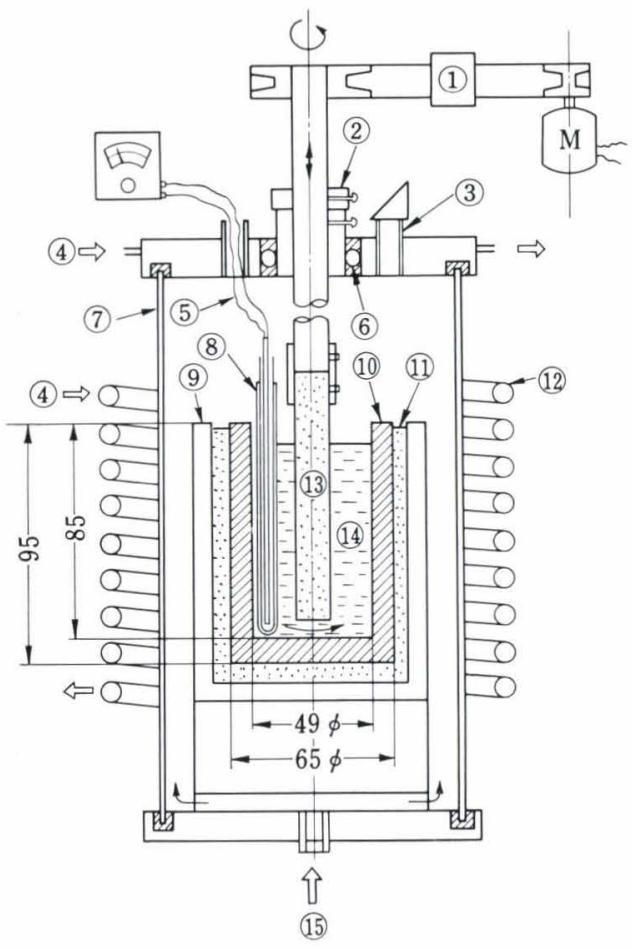

(1) Vari-speeder
(2) Stopper
(3) Observation and sampl-
ing hall
(4) Cooling water
(5) $6 \mathrm{RhPt}-30 \mathrm{RhPt}$
(6) Ball bearing
(7) Silica tube
(8) Pure iron cap
(9) Magnesia crucible
(10) Pure iron crucible
(11) Magnesia powder
(12) Induction coil
(13) Graphite roter
(14) Fayalite (Sample)
(15) Argon gas

Fig. 1. Experimental apparatus

slag, the rotation was immediately started. The first sampling was made after the liquid was stirred uniformly. The sampling was made every 5 to $10 \mathrm{~min}$ with a steel rod and its amount was 2 to $3 \mathrm{~g}$. The depth of liquid was measured by the adhered slag length on the steel rod. The experimental temperature was ranged from $1350^{\circ}$ to $1450^{\circ} \mathrm{C}$, because the crucible was made of pure iron.

\section{Sample}

The range of $\mathrm{FeO}$ concentration in slag was rather restricted, because the slag must be kept in liquid state during the whole period of reaction in the above mentioned temperature range.

Some examples of initial FeO concentration in slags used for experiments are shown in Fig. 2. The range of slag composition were as follows:

(i) $\mathrm{FeO}-\mathrm{SiO}_{2} ; \mathrm{FeO} 60$ to $80 \%$

(ii) $\mathrm{FeO}-\mathrm{SiO}_{2}-\mathrm{CaO} ; \mathrm{FeO} 20$ to $80 \%, \mathrm{SiO}_{2} 45$ to $10 \%, \mathrm{CaO} 35$ to $5 \%$

(iii) $\mathrm{FeO}-\mathrm{SiO}_{2}-\mathrm{Al}_{2} \mathrm{O}_{3} ; \mathrm{FeO} 40$ to $80 \%, \mathrm{Al}_{2} \mathrm{O}_{3} 15$ to $5 \%, \mathrm{SiO}_{2} 45$ to $15 \%$

(iv) $\mathrm{FeO}-\mathrm{SiO}_{2}-\mathrm{MgO} ; \mathrm{FeO} 65$ to $80 \%, \mathrm{MgO} 5 \%$, $\mathrm{SiO}_{2} 30$ to $15 \%$

(v) $\mathrm{FeO}-\mathrm{SiO}_{2}-\mathrm{Al}_{2} \mathrm{O}_{3}-\mathrm{CaO} ; \mathrm{FeO} 5$ to $30 \%\left(1350^{\circ} \mathrm{C}\right)$

(vi) $\mathrm{FeO}-\mathrm{SiO}_{2}-\mathrm{Al}_{2} \mathrm{O}_{3}-\mathrm{MgO} ; \quad \mathrm{FeO} \quad 5$ to $30 \%$ (1 $350^{\circ} \mathrm{C}$ )

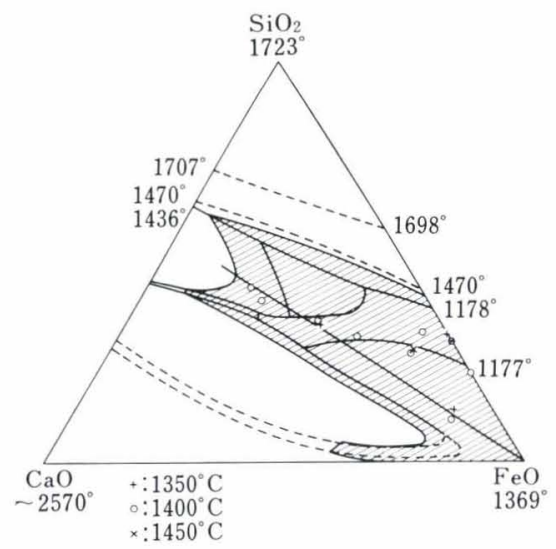

Fig. 2. Initial composition of samples about system FeO$\mathrm{SiO}_{2}-\mathrm{CaO}$ showing liquidus range at $1400^{\circ} \mathrm{C}$

\section{Experimental Result and Discussion}

1. State of Sample during Reduction

The slag temperature fell about $30^{\circ} \mathrm{C}$ just after the graphite rod was put into the slag, but recovered to the previous one after a few minutes. The molten slag depth was about $50 \mathrm{~mm}$ at first. At the just beginning of reduction, it increased owing to the $\mathrm{CO}$ gas generated by $\mathrm{FeO}$ reduction and decreased gradually as $\mathrm{FeO}$ concentration in slag decreased.

In case of the rapid reaction a phenomenon of "foaming" occured and sample in a crucible sometimes overflowed (this is referred later).

Metallic iron reduced from $\mathrm{FeO}$ mostly deposited at the bottom of the crucible. According to spectroscopic analysis, silicon was hardly determined and carbon was less than $0.6 \%$ (Table 1). Therefore, it was assumed that the reduction of $\mathrm{FeO}$ with carbon contained in the reduced iron was little.

\section{Experimental Results}

During the experimental runs the diameter of carbon rod, and thus, the area of reaction surface decreased and the stirring condition might change. Therefore, the data for analysis are only those, in which the changes of temperature and the reaction surface were less than $10 \%$ and the decrease of $\mathrm{FeO}$ in charged slag was less than $20 \%$. An example of slag composition change in an experiment is shown in Table 2.

The rate of surface reaction under an isothermal condition is generally defined by the following equation.

$$
r=-\frac{1}{A}\left(\frac{d n}{d t}\right)
$$

where, $r$ : reaction rate

$n$ : $\mathrm{FeO}$ mol number in slag

$A$ : surface area of reaction

$t$ : time.

If the reaction rate is linearly proportional to the $\mathrm{FeO}$ mol concentration, it can be expressed by the following equation.

$$
r=-\frac{1}{A} \frac{d n}{d t}=K_{1} C=K_{1} \frac{n}{V}
$$

where, $V$ : liquid volume

$K_{1}$ : the first-order reaction rate constant. 
If $V$ and $A$ do not change during $\mathrm{FeO}$ reduction, the above differential equation can be solved with an initial condition $n=n_{0}$ at $t=0$

$$
-\frac{V}{A} \ln \left(\frac{n}{n_{0}}\right)=K_{1} t
$$

where, $n_{0}$ : initial $\mathrm{FeO}$ mol number

$$
n: \text { FeO mol number at time } t \text {. }
$$

$n$ is determined taking into account that $\mathrm{SiO}_{2}$ in slag does not decrease during reduction. That is, $n_{0}$ and $n$ are given by

$$
\begin{aligned}
n_{0} & =W_{i}\left(\mathrm{Fe}^{++}-M . \mathrm{Fe}\right)_{i} / 55.85 \\
n & =W_{t}\left(\mathrm{Fe}^{++}-M . \mathrm{Fe}\right)_{t} / 55.85
\end{aligned}
$$

where, $W$ : slag weight

$\mathrm{Fe}^{++}$: weight fraction of ferrous oxide

M.Fe: weight fraction of metallic iron

$$
W_{t}=W_{i} \times\left(\mathrm{SiO}_{2}\right)_{i} /\left(\mathrm{SiO}_{2}\right)_{t}
$$

$\mathrm{SiO}_{2}$ : weight fraction of silica.

The subscripts $i$ and $t$ refer to initial time $(t=0)$ and $t=t$, respectively and initial time was decided the first sampling time. The reaction rate constant, $K_{1}$, can be calculated by use of these values. The several experimental results are plotted in Fig. 3. Because the linearity of $(V / A) \ln \left(n / n_{0}\right)$ vs. time in each experiment is fairly well, the assumption of the first order reaction with respect to the iron oxide concentration may be accepted within a small range of the concentration change.

\section{Effect of Revolutional Speed of Rod}

In the range of small revolutional speed of carbon rod, the reaction rate increased with the revolutional

\begin{tabular}{|c|c|c|c|c|c|}
\hline \multirow{2}{*}{$\begin{array}{l}\text { Exp. } \\
\text { No. }\end{array}$} & \multirow{2}{*}{$\begin{array}{l}\text { Initial composition } \\
\text { of sample }\end{array}$} & \multirow{2}{*}{$\begin{array}{l}\text { Reduc- } \\
\text { tion } \\
\text { temp. } \\
\left({ }^{\circ} \mathrm{C}\right)\end{array}$} & \multicolumn{2}{|c|}{$\mathrm{Si}(w \mathrm{t} \%)$} & \multirow{2}{*}{$\begin{array}{l}\mathrm{C} \% \\
\text { in red. } \\
\text { iron }\end{array}$} \\
\hline & & & Crucible & $\begin{array}{l}\text { Red. } \\
\text { iron }\end{array}$ & \\
\hline 7 & $2 \mathrm{FeO} \cdot \mathrm{SiO}_{2}$ & 1350 & $<0.05$ & $<0.05$ & 0.6 \\
\hline 20 & $\mathrm{FeO} 80: \mathrm{SiO}_{2} 20$ & 1400 & $<0.05$ & $<0.05$ & 0.4 \\
\hline 28 & $\mathrm{FeO} 90: \mathrm{SiO}_{2} 10$ & 1400 & $<0.05$ & 0.07 & 0.5 \\
\hline 29 & $\begin{array}{rl}2 \mathrm{FeO} \cdot \mathrm{SiO}_{2} & 96 \\
\mathrm{TiO}_{2} & 4\end{array}$ & 1450 & $<0.05$ & 0.06 & 0.2 \\
\hline
\end{tabular}
speed. However, it became constant at the revolutional speed above $400 \mathrm{rpm}$. The effect of rotation of carbon rod upon reaction curve and rate constant

Table 1. Silicon and carbon percent in the reduced iron

Table 2. An example of experimental data (slag composition: $2 \mathrm{FeO}-\mathrm{SiO}_{2}$, reduction temp.: $1350^{\circ} \mathrm{C}$, rotation speed : $840 \mathrm{rpm}$ )

\begin{tabular}{c|c|c|c|c|c}
\hline $\begin{array}{c}\text { Sampling } \\
\text { No. }\end{array}$ & $\begin{array}{c}\text { Time } \\
(\mathrm{min})\end{array}$ & $\begin{array}{c}\text { T. Fe } \\
(\%)\end{array}$ & $\begin{array}{c}\text { M. Fe } \\
(\%)\end{array}$ & $\begin{array}{l}\mathrm{FeO} \\
(\%)\end{array}$ & $\begin{array}{c}\mathrm{SiO}_{2} \\
(\%)\end{array}$ \\
\hline 1 & 0 & 53.48 & 0.98 & 63.51 & 29.40 \\
2 & 15 & 53.56 & 1.12 & 63.94 & 30.45 \\
3 & 30 & 51.80 & 0.98 & 61.96 & 32.35 \\
4 & 45 & 50.82 & 1.14 & 61.06 & 33.55 \\
5 & 60 & 49.15 & 1.12 & 58.84 & 33.70 \\
6 & 75 & 48.31 & 1.17 & 58.77 & 36.00 \\
& & & & &
\end{tabular}

is shown in Figs. 3 and 4 . In these figures, $d$ is diameter of the carbon rod, $\mathcal{N}$ is revolution per second and hence $d^{2} \mathcal{N}$ is the value proportional to Reynolds number of a rotating speed. The reaction rate did not increase under the condition that $d^{2} \mathcal{N}$ is more than $50 \mathrm{~cm}^{2} / \mathrm{sec}(d=2.0 \mathrm{~cm}, \mathcal{N}=750 \mathrm{rpm})$ and this relationship was confined to be valid for other multi-component slag systems. Therefore, the experimental data with $d^{2} \mathcal{N}$ value over $50 \mathrm{~cm}^{2} / \mathrm{sec}$ were used for the analysis of the chemical reaction rate.

\section{Chemical Reaction Rate Analysis by Differential Method}

Results of calculation of reaction rate with $d^{2} \mathcal{N}$ value over $50 \mathrm{~cm}^{2} / \mathrm{sec}$ are given in Table 3 . In this

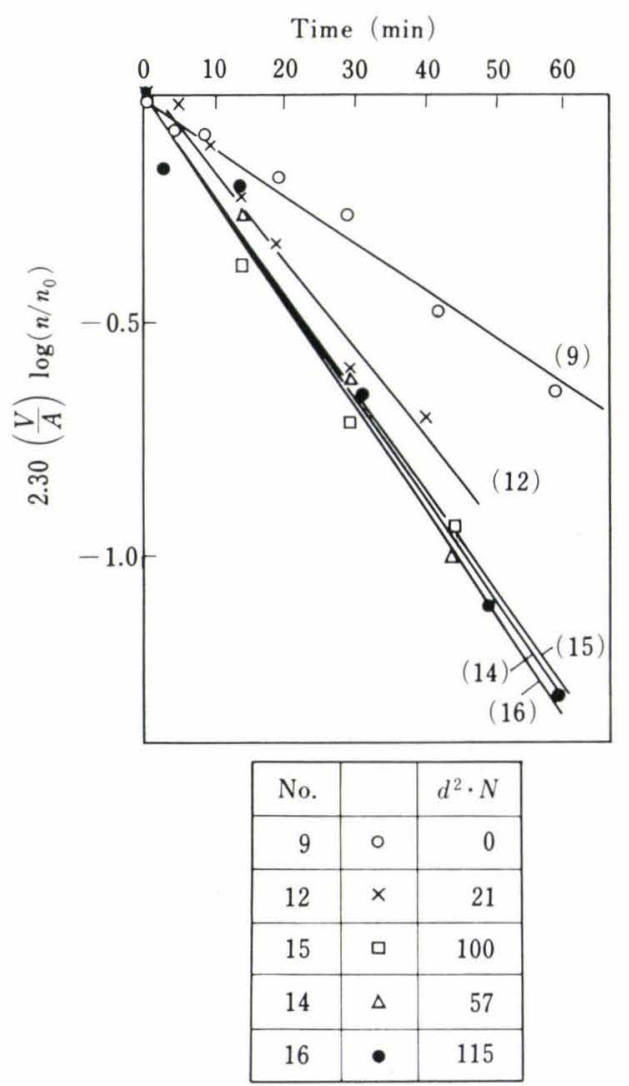

Fig. 3. Relationship between revolution of carbon rod and change of $\mathrm{FeO}$ concentration with $2 \mathrm{FeO} \cdot \mathrm{SiO}_{2}$ system at $1400^{\circ} \mathrm{C}(V$ : slag volume, $A$ : reaction surface, $n$ : FeO concentration, $n_{0}$ : initial FeO concentration)

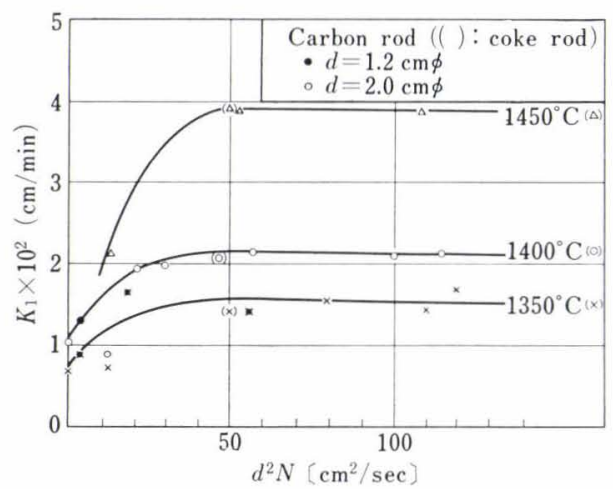

Fig. 4. Effect of ratation of carbon and coke rod on the $\mathrm{FeO}$ reduction rate concerning the system $\mathrm{FeO}-\mathrm{SiO}_{2}$ (d: diameter of $\operatorname{rod}, \mathcal{N}$ : revolutions per sec) 
table, $A$ is the reaction surface area of rod excluding the bottom surface because of latter treatment (error for neglect of bottom surface is within 10\%) and $V$ is the slag volume. These values were calculated from the length of slag adhered to the sampling rod. Analysed values of metallic iron at $t=0$ denote the reduced iron in the period until slag temperature settles to an appointed value before the first sampling. Metallic iron was almost suspended in slag because of its small size. Each value of $(1 / A)(d n / d t)$ and $(W / A)$. $\left(d C_{1} / d t\right)$ are obtained from the slope of the FeO concentration against time and are expressed the value of reaction rate with mol and weight percent as $\mathrm{FeO}$ concentration. $K_{1}$ express the first order reaction rate constants calculated on the above-mentioned assumption that reaction order is first with respect to mol concentration of $\mathrm{FeO}\left(\mathrm{mol} \mathrm{FeO} / \mathrm{cm}^{3}\right)$. Either $\mathrm{wt}^{\%} \%$ or $\mathrm{mol}_{\%} \%$ of $\mathrm{FeO}$ can be used in the limited range of

Table 3. Summary of experimental results for the calculation of reduction rate

\begin{tabular}{|c|c|c|c|c|c|c|c|c|c|c|c|c|c|}
\hline \multirow{2}{*}{$\begin{array}{l}\text { Exp. } \\
\text { No. }\end{array}$} & \multirow{2}{*}{$\begin{array}{l}W_{i} \\
(\mathrm{~g})\end{array}$} & \multirow{2}{*}{$\begin{array}{c}A \\
\left(\mathrm{~cm}^{2}\right)\end{array}$} & \multirow{2}{*}{$\underset{\left(\mathrm{cm}^{3}\right)}{V}$} & \multicolumn{7}{|c|}{ Analyzed value at $t=0(w \mathrm{t} \%)$} & \multirow{2}{*}{$\begin{array}{l}\left(\frac{1}{A} \cdot \frac{d n}{d t}\right) \\
(\mathrm{mol} / \\
\left.\mathrm{cm}^{2} \mathrm{~min}\right) \\
\left(\times 10^{-3}\right)\end{array}$} & \multirow{2}{*}{$\begin{array}{l}\left(\frac{W}{A} \cdot \frac{d C_{1}}{d t}\right) \\
(g / \\
\left.\mathrm{cm}^{2} \min \right) \\
\left(\times 10^{-2}\right)\end{array}$} & \multirow{2}{*}{$\begin{array}{c}K_{1} \\
(\mathrm{~cm} / \\
\mathrm{min}) \\
\left(\times 10^{-1}\right)\end{array}$} \\
\hline & & & & T. Fe & $M . \mathrm{Fe}$ & $\mathrm{Fe}_{t} \mathrm{O}$ & $\mathrm{SiO}_{2}$ & $\mathrm{CaO}$ & $\mathrm{Al}_{2} \mathrm{O}_{3}$ & $\mathrm{MgO}$ & & & \\
\hline \multicolumn{14}{|l|}{$1350^{\circ} \mathrm{C}$} \\
\hline 99 & 280 & 31.4 & 97.4 & 53.48 & 0.98 & 67.99 & 29.40 & - & - & - & 0.30 & 0.81 & 0.12 \\
\hline 100 & 280 & 31.4 & 97.4 & 54.51 & 0.84 & 73.04 & 27.50 & - & - & - & 0.35 & 0.75 & 0.14 \\
\hline 101 & 280 & 31.4 & 97.4 & 54.48 & 1.78 & 67.91 & 28.20 & - & - & - & 0.38 & 0.98 & 0.15 \\
\hline 102 & 280 & 31.4 & 97.4 & 54.54 & 0.79 & 69.38 & 28.10 & - & - & - & 0.33 & 1.03 & 0.13 \\
\hline 55 & 280 & 38.1 & 114.2 & $3 \cap$ o & 2.01 & 38.13 & 32.20 & 22.73 & - & - & 0.70 & 2.13 & 0.59 \\
\hline 112 & 280 & 37.0 & 111.5 & 48.27 & 1.45 & 60.66 & 24.85 & 10.27 & - & - & 0.69 & 2.72 & 0.36 \\
\hline 115 & 280 & 31.9 & 98.6 & 49.20 & 0.59 & 63.22 & 26.85 & - & 9.68 & - & 0.53 & 1.91 & 0.23 \\
\hline 52 & 280 & 25.8 & 83.4 & 60.26 & 0.92 & 77.04 & 13.95 & - & 5.77 & - & 1.16 & 2.72 & 0.38 \\
\hline 29 & 280 & 27.6 & 88.0 & 52.02 & 0.87 & 66.25 & 26.85 & - & - & 4.26 & 0.66 & 2.04 & 0,25 \\
\hline 27 & 280 & 27.0 & 86.5 & 48.78 & 0.78 & 62.27 & 25.45 & 5.11 & 5.22 & - & 0.56 & 2.01 & 0.22 \\
\hline 32 & 200 & 18.2 & 64.5 & 5.72 & 0.75 & 6.61 & 45.95 & 30.83 & 9.78 & 5.56 & 0.01 & 0.09 & 0.05 \\
\hline 119 & 230 & 25.1 & 81.7 & 12.49 & 0.0 & 16.37 & 33.70 & 32.90 & 9.29 & 5.89 & 0.16 & 0.46 & 0.26 \\
\hline \multicolumn{14}{|l|}{$1400^{\circ} \mathrm{C}$} \\
\hline 103 & 280 & 31.4 & 97.4 & 54.17 & 1.90 & 67.57 & 30.35 & - & - & - & 0.46 & 1.17 & 0.20 \\
\hline 104 & 280 & 31.4 & 97.4 & 54.17 & 0.84 & 69.17 & 29.75 & - & - & & 0.48 & 1.34 & 0.20 \\
\hline 105 & 280 & 31.4 & 97.4 & 54.23 & 0.78 & 69.20 & 30.60 & - & - & - & 0.47 & 1.28 & 0.20 \\
\hline 106 & 250 & 15.0 & 89.7 & 53.90 & 0.81 & 68.63 & 28.10 & - & - & - & 0.43 & 1.14 & 0.18 \\
\hline 109 & 350 & 40.8 & 121.0 & 59.93 & 0.70 & 76.77 & 20.85 & - & - & - & 0.61 & 1.66 & 0.26 \\
\hline 110 & 350 & 40.8 & 121.0 & 60.60 & 0.92 & 77.29 & 20.35 & - & - & - & 0.69 & 1.57 & 0.25 \\
\hline 13 & 280 & 28.5 & 90.3 & 61.07 & 1.14 & 77.80 & 20.10 & - & - & - & 0.84 & 1.39 & 0.28 \\
\hline 111 & 350 & 32.6 & 100.5 & 68.50 & 0.84 & 88.50 & 9.48 & - & - & - & 1.86 & 1.62 & 0.50 \\
\hline 43 & 200 & 22.4 & 74.9 & 17.13 & 0.11 & 22.24 & 43.35 & 33.62 & - & - & 0.10 & 0.51 & 0.13 \\
\hline 41 & 200 & 31.5 & 97.7 & 30.05 & 1.82 & 37.41 & 33.35 & 23.85 & - & - & 0.51 & 1.97 & 0.56 \\
\hline 39 & 200 & 36.0 & 108.9 & 38.15 & 2.49 & 46.69 & 29.70 & 20.34 & - & - & 0.76 & 3.32 & 0.93 \\
\hline 25 & 280 & 28.2 & 89.5 & 46.48 & 0.95 & 58.74 & 28.40 & 4.70 & - & - & 0.74 & 2.60 & 0.34 \\
\hline 113 & 280 & 34.9 & 106.2 & 48.39 & 1.68 & 60.60 & 25.45 & 10.30 & - & - & 0.83 & 3.43 & 0.41 \\
\hline 30 & 280 & 27.6 & 88.0 & 51.19 & 0.89 & 65.01 & 27.00 & - & - & 5.10 & 0.87 & 2.39 & 0.32 \\
\hline 40 & 200 & 18.4 & 64.9 & 61.60 & 1.42 & 78.54 & 14.70 & - & - & 4.40 & 1.29 & 2.60 & 0.46 \\
\hline 51 & 280 & 41.9 & 123.8 & 33.23 & 0.56 & 42.15 & 43.70 & - & 14.38 & - & 0.45 & 3.01 & 0.35 \\
\hline 24 & 280 & 28.7 & 90.8 & 47.78 & 1.62 & 59.44 & 31.00 & - & 5.09 & - & 0.50 & 1.58 & 0.21 \\
\hline 116 & 280 & 33.3 & 102.1 & 48.89 & 0.56 & 63.13 & 23.95 & - & 9.10 & - & 0.65 & 1.92 & 0.33 \\
\hline 117 & 280 & 29.1 & 91.7 & 48.48 & 0.89 & 61.72 & 25.35 & - & 13.30 & - & 0.74 & 2.24 & 0.33 \\
\hline 23 & 280 & 29.0 & 91.6 & 46.89 & 0.89 & 60.21 & 22.95 & - & 15.79 & - & 1.00 & 3.13 & 0.43 \\
\hline 50 & 280 & 29.5 & 92.7 & 60.54 & 0.95 & 77.59 & 14.45 & - & 5.86 & - & 0.92 & 2.03 & 0.33 \\
\hline 22 & 200 & 12.0 & 49.0 & 5.53 & 0.0 & 7.28 & 31.10 & 31.35 & 9.50 & 6.65 & 0.08 & 0.58 & 0.30 \\
\hline 26 & 280 & 29.5 & 92.8 & 48.78 & 0.72 & 62.36 & 25.60 & 5.05 & 5.13 & - & 0.80 & 0.28 & 0.36 \\
\hline \multicolumn{14}{|l|}{$1450^{\circ} \mathrm{C}$} \\
\hline 107 & 280 & 31.4 & 97.4 & 54.43 & 1.06 & 69.06 & 28.40 & - & - & - & 0.79 & 2.49 & 0.37 \\
\hline 108 & 280 & 31.4 & 97.4 & 54.73 & 0.92 & 69.42 & 27.90 & - & - & - & 0.84 & 2.61 & 0.37 \\
\hline 114 & 280 & 31.2 & 97.1 & 48.08 & 1.23 & 60.98 & 25.00 & 8.10 & - & - & 1.10 & 4.30 & 0.54 \\
\hline 118 & 280 & 29.1 & 91.7 & 48.32 & 0.89 & 61.88 & 25.80 & - & 10.20 & - & 1.01 & 5.95 & 0.46 \\
\hline 38 & 200 & 22.0 & 74.0 & 5.61 & 0.89 & 6.10 & 42.30 & 29.77 & 9.19 & 5.48 & 0.02 & 1.51 & 0.11 \\
\hline
\end{tabular}


the $\mathrm{FeO}$ concentration. However $\mathrm{FeO}$ activity must be generally used for the wide range of the FeO concentration. In order to analyse the reduction rate on the basis of the activity of iron oxide " FeO," its value in the present experimental conditions must be known.

The "FeO" activity in the present experimental temperatures has been investigated on $\mathrm{FeO}-\mathrm{SiO}_{2}$ and $\mathrm{FeO}-\mathrm{SiO}_{2}-\mathrm{CaO}$ systems. Bodsworth et al. ${ }^{6,7)}$ have determined $\mathrm{FeO}$ activity in $\mathrm{FeO}-\mathrm{SiO}_{2}-\mathrm{CaO}$ slag at temperatures between $1265^{\circ}$ and $1365^{\circ} \mathrm{C}$. But the value of $\mathrm{FeO}$ activity at $1400^{\circ} \mathrm{C}$, which are necessary for the present calculation, has not been determined experimentally. However, they extrapolated FeO activities at $1600^{\circ} \mathrm{C}$ from their data obtained in the range between $1265^{\circ}$ and $1365^{\circ} \mathrm{C}$ and found that these values agreed well with those measured by Elliott. ${ }^{9)}$ Therefore, $\mathrm{FeO}$ activity in $\mathrm{FeO}-\mathrm{SiO}_{2}-\mathrm{CaO}$ slag at $1400^{\circ}$ and $1450^{\circ} \mathrm{C}$ can be estimated by means of interpolating from Elliott's data at $1600^{\circ} \mathrm{C}$ and Bodsworth's ones between $1265^{\circ}$ and $1365^{\circ} \mathrm{C}$. Activity diagrams thus obtained are shown in Fig. 5. Furthermore, assuming that the effect of $\mathrm{MgO}$ on the $\mathrm{FeO}$ activity is nearly equal to that of $\left.\mathrm{CaO},{ }^{8}\right) \mathrm{FeO}$ activity in $\mathrm{FeO}-\mathrm{SiO}_{2}-\mathrm{MgO}$ slag can also be estimated.

The reaction rates $(1 / A)(d n / d t)$ for $\mathrm{FeO}-\mathrm{SiO}_{2}, \mathrm{FeO}-$ $\mathrm{SiO}_{2}-\mathrm{CaO}$, and $\mathrm{FeO}-\mathrm{SiO}-\mathrm{MgO}$ slags at $1350^{\circ}, 1400^{\circ}$, and $1450^{\circ} \mathrm{C}$ are plotted in Fig. 6 against FeO activity which is obtained from Fig. 5. The slopes of lines for each slag system are almost the same as shown in Fig. 6(b) except two points in high $\mathrm{FeO}$ activity range. Especially in spite of the wide composition range concerning with $\mathrm{FeO}-\mathrm{SiO}_{2}-\mathrm{CaO}$ slag, it is interesting that data are on the same line. The average of slopes
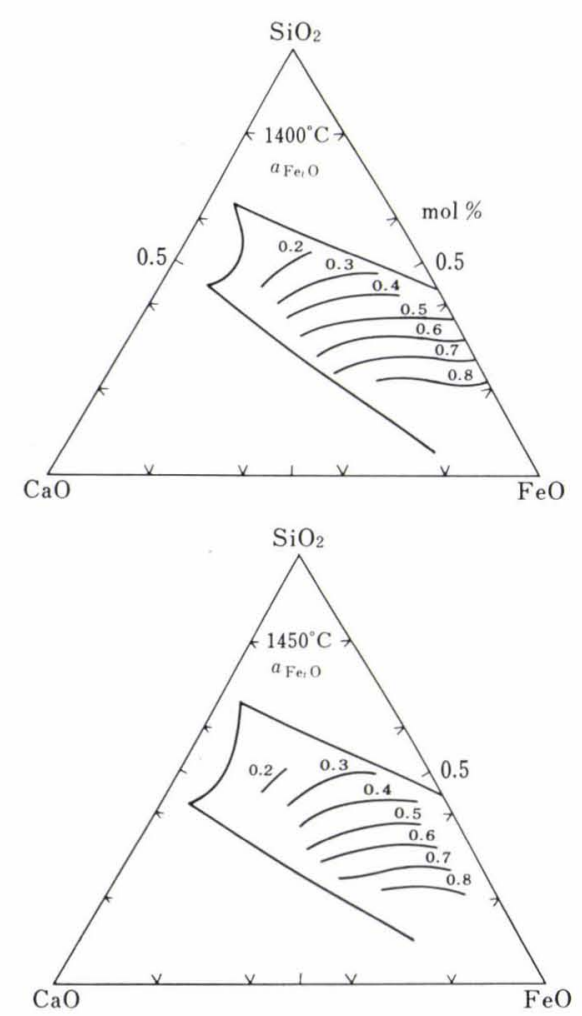

Fig. 5. Activity of $\mathrm{FeO}$ in the system $\mathrm{FeO}-\mathrm{SiO}_{2}-\mathrm{CaO}$ calculated from the results of Bodsworth ${ }^{\text {7) }}$ and Elliott ${ }^{9}$ of these lines reaction order is about 1.15 within the error of 0.2 concerning with two and three component slag as shown in Table 4. The lines considered that the reaction rate is proportional to the first order of $\mathrm{FeO}$ activity, are drawn with bold lines in Fig. 6 in relation to each temperature. All reaction rate can be expressed by these lines within errors of $30 \%$. Therefore, the reduction rate of $\mathrm{FeO}$ in slag can be considered to be proportional to FeO activity. The activation energy of the reaction calculated from these results is $39.7 \mathrm{kcal} / \mathrm{mol}$. The obtained reaction rate equation is as follows:

$$
\dot{n}_{\mathrm{FeO}}=-1.73 \times 10^{2} \times A \times \exp (-39700 / R T) \times a_{\mathrm{FeO}}
$$

where, $\dot{n}_{\mathrm{FeO}}$ : rate of reduction in mol number of $\mathrm{FeO}$ in slag per minute

$A$ : surface area of reaction $\left(\mathrm{cm}^{2}\right)$

$a_{\mathrm{FeO}}$ : activity of $\mathrm{FeO}$ based on mol fraction.

But, strictly speaking there are two problems in this result. These are, (1) the chemical reaction rate is affected not only by "FeO" activity but also by the variation of slag component, and (2) the very fast reaction rate in case of high $\mathrm{FeO}$ content at $1400^{\circ} \mathrm{C}$. Probably these problems can be thought to originate from the facts that the activities itself include certain magnitude of error, that $\mathrm{Fe}^{++}$and $\mathrm{Fe}^{+++}$might not be in equilibrium enough at the beginning of reaction, and that the state of reaction surface depending on generation and separation of $\mathrm{CO}$ bubbles are different with slag systems. Exact interpretation of these problems still remain unsolved.

In order to compare with the conclusion based on $\mathrm{FeO}$ acitivity, the reaction rate calculated from same data using weight percent $\mathrm{FeO}$ is shown in Fig. 7. The reaction rate differs considerably with slag composition in spite of the same $\mathrm{FeO}$ percent. Gradients of these lines reaction orders are in the range from

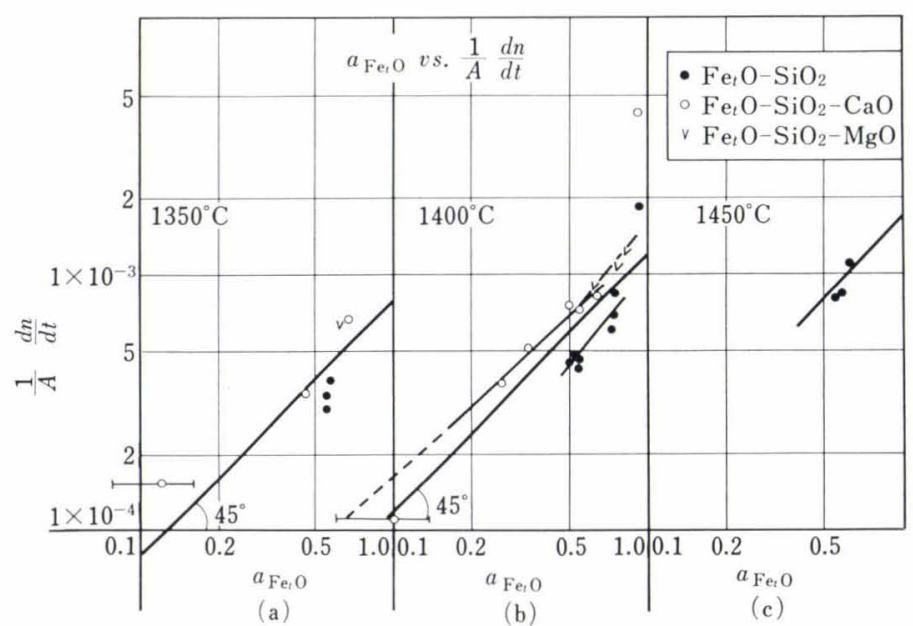

Fig. 6. Differential plot of $\mathrm{FeO}$ reduction concerning with $\mathrm{FeO}$ activity

Table 4. Apparent order of reaction determined by the differential method (at $1400^{\circ} \mathrm{C}$ )

\begin{tabular}{ccc}
$\mathrm{FeO}-\mathrm{SiO}_{2}$ & $\mathrm{FeO}-\mathrm{SiO}_{2}-\mathrm{CaO}$ & $\mathrm{FeO}-\mathrm{SiO}_{2}-\mathrm{MgO}$ \\
\hline 1.26 & 0.89 & 1.31
\end{tabular}


1.0 to 4.0 as shown in the following equation. From this fact, it is difficult to express the reaction rate consistently as a function of $\mathrm{FeO}$ weight percent regardless of difference of slag component. In case of mol fraction of $\mathrm{FeO}$, the same conclusion was derived.

Rate equations using weight percent at $1400^{\circ} \mathrm{C}$ are expressed for each slag system as follows.

$\mathrm{FeO}-\mathrm{SiO}_{2}$ :

$$
(1 / A) \times \dot{n}_{\mathrm{FeO}}=-1.31 \times 10^{-2} \times\left(\% \mathrm{FeO} \times 10^{-2}\right)^{3.79}
$$

$\mathrm{FeO}-\mathrm{SiO}_{2}-\mathrm{CaO}\left(\mathrm{CaO} / \mathrm{SiO}_{2}=11 / 9\right)$ :

$$
(1 / A) \times \dot{n}_{\mathrm{FeO}}=-7.16 \times 10^{-2} \times\left(\% \mathrm{FeO} \times 10^{-2}\right)^{2.70}
$$

$\mathrm{FeO}-\mathrm{SiO}_{2}-\mathrm{MgO}\left(\mathrm{SiO}_{2} / \mathrm{MgO}=17 / 9\right)$ :

$(1 / A) \times \dot{n}_{\mathrm{FeO}}=-2.06 \times 10^{-2} \times\left(\% \mathrm{FeO} \times 10^{-2}\right)^{2.14}$

$\mathrm{FeO}-\mathrm{SiO}_{2}-\mathrm{Al}_{2} \mathrm{O}_{3}\left(\mathrm{SiO}_{2} / \mathrm{Al}_{2} \mathrm{O}_{3}=8 / 2\right)$ :

$(1 / A) \times \dot{n}_{\mathrm{FeO}}=-1.15 \times 10^{-2} \times\left(\% \mathrm{FeO} \times 10^{-2}\right)^{1 .}{ }^{07}$

After all it is most reasonable that chemical reaction rate is considered to be proportional to the first order of " $\mathrm{FeO}$ " activity.

\section{Reaction Mechanism}

\section{At Higher Rotating Speed (above $50 \mathrm{~cm}^{2} / \mathrm{sec}$ as $d^{2} \mathcal{N}$ )}

In relation to the $\mathrm{FeO}$ reduction in molten slag, the following elementary processes are considered. ${ }^{1)}$

(1) Transfer of $\mathrm{FeO}$ to the reaction surface

(2) Interface reaction
(a)

$$
\begin{aligned}
& \mathrm{FeO}+\mathrm{C}=\mathrm{Fe}+\mathrm{CO} \\
& \mathrm{FeO}+\mathrm{CO}=\mathrm{Fe}+\mathrm{CO}_{2} \\
& \mathrm{C}+\mathrm{CO}_{2}=2 \mathrm{CO}
\end{aligned}
$$

(3) Separation of the reaction products from the reaction surface.

In order to investigate the rate-determining step, $\mathrm{CO}$ gas was blown into molten slag with a flow rate of 50 to $360 \mathrm{cc} / \mathrm{min}$. This amount is about 15 times $\mathrm{CO}$ gas produced during a run of experiment with the carbon rod. The amount of reduction by blown CO gas was 5 to $10 \%$ by the graphite rod. This fact shows that the reaction (b) is not so important. It may be thus improbable that (c) is an important side

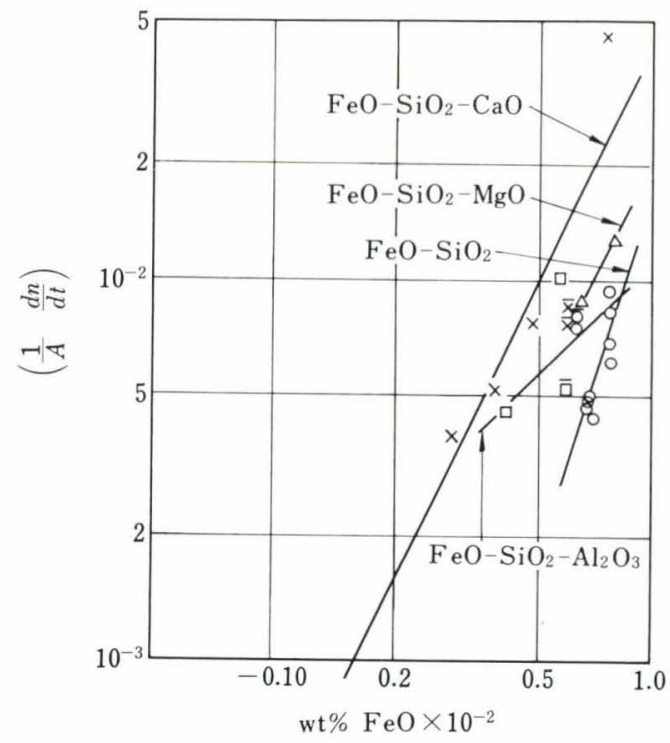

Fig. 7. Differential plot of $\mathrm{FeO}$ reduction concerning with $\mathrm{wt} \% \mathrm{FeO}$ reaction. There was no difference in the reduction rate between a graphite rod and a coke rod as shown in Fig. 4 regardless of the difference of surface condition. There are notable differences in the reduction rate constant and the reaction order due to the differences in slag components. So it is reasonable to consider that (a) is the rate determining reaction under high rotating speed of rod, because data in the wide range of temperature and slag composition can be well summarized and the reaction order is close to 1.0 with respect to the activity of $\mathrm{FeO}$. If the interdiffusion of $\mathrm{FeO}$ is the rate determining step, the reaction rate must increase as rotational speed of the graphite rod increases. But the reaction rate becomes constant as shown in Fig. 4. In order to explain this phenomenon tentatively, bubbles produced by reduction need to act just so as to cancell the effect of rotational speed. It is very difficult to consider that bubble has effect on reaction just like this interpretation. As a consequence, it is the most reasonable to consider that the chemical reaction (a) is the rate determining step because experimental results can be well explained with use of $\mathrm{FeO}$ activity in molten slag.

\section{At Lower Rotating Speed of Rod (under $50 \mathrm{~cm}^{2} / \mathrm{sec}$ with $\left.d^{2} \mathcal{N}\right)$}

In this range rate-determining step is considered to be mixed one with iron oxide diffusion and chemical reaction, becauce reaction rate increases with revolution speed of rod. Furthermore one of characteristics of this reaction is bubble generation. This has direct effects upon FeO diffusion in laminar film. In the following this is discussed.

Assuming that the reaction is the first order one with $\mathrm{mol} \%$ to simplify the treatment, the total reaction rate constant is estimated in the following equation,

$$
1 / K=1 / K_{c}+1 / K_{f}
$$

where, $K$ : the overall reaction rate constant

$K_{c}$ : chemical reaction rate constant

$K_{f}$ : mass transfer coefficient.

$K_{f}$ can be considered much larger than $K_{c}\left(K_{f} \gg K_{c}\right)$ in the range where $K$ does not change with rotational speed of the rod. Therefore, $K$ can be supposed equal to $K_{c} . \quad K_{f}$, in the range of which $K$ is affected with rotational speed, can be easily obtained from $K$ and $K_{c}$.

Bubbles generated by the reduction should have various effects on the mass transfer between slag and graphite rod. In case of no bubble formation, Eisenberg $^{9)}$ has derived the equation concerning the mass transfer in a radial direction of rod between benzoic acid (solid) and water-glycerol solution.

The equation is

$$
J=\left(K_{L} / V_{1}\right) \times S_{c}^{0.644}=0.0791 \times\left(R_{e}\right)^{-0.3}
$$

where, $K_{L}$ : mass transfer coefficient,

$V_{1}$ : peripheral velocity,

$S_{c}$ : Schmidt number $(=\mu / \rho D)$,

$R_{e}$ : $\operatorname{rod}$ Reynolds number, $\left(V_{l} \cdot d / \nu\right)$,

$D$ : diffusion coefficient. 
The effect of bubbles can be shown by the ratio of $K_{f}$ to $K_{L}$ calculated with the above equation. In this calculation, the diffusion coefficient of $\mathrm{FeO}$ is $3.784 \times$ $10^{-4} \mathrm{~cm}^{2} / \mathrm{sec}$, according to Mori et al..$^{10,11)}$, and $K_{L}$ is corrected as the mean mol fraction of slag components except $\mathrm{FeO}$ is same.

The obtained value of $K_{f} / K_{L}$ is closely related to the generating rate of bubbles, i.e. $K_{c}$, and is not related to Reynolds number of rotation as shown in Fig. 8. Bubbles are considered to act to obstruct the diffusion of reactants to the reaction surface as they attach to the reaction surface in the range of $K_{f} / K_{L}<1$, and in the range of $K_{f} / K_{l}>1$ to disturb the laminar film and to accelerate $\mathrm{FeO}$ diffusion, when they separate from the reaction surface.

Behavior of bubble is very complex and important for reaction. So it should be studied more in details.

In addition to the above mentioned, Foaming phenomena were often observed in a certain experiments. Especially vigorous foaming occurred in some slag composition and the slag overflowed from the crucible. This phenomenon notably occurred in the slag with high $\mathrm{Al}_{2} \mathrm{O}_{3}$ and $\mathrm{CaO}$ concentration. Foaming is related to the amount and rate of $\mathrm{CO}$ gas generation by $\mathrm{FeO}$ reduction. Furthermore slag properties, especially the relationship between viscosity and surface tension, has effect on the slag foaming (Fig. 9).

\section{Conclusion}

Following conclusions are obtained as a result of investigation with the reduction of $\mathrm{FeO}$ in molten slag by carbon rod.

(1) At high rotation speed the rate is not affected by the notation speed and the reduction rates obtained from the experimental data can be best expressed, when they are assumed to be proportional to the first order of FeO activity in slags. The obtained chemical reaction rate equation is

$$
(-1 / A) \dot{n}_{\mathrm{FeO}}=1.73 \times 10^{2} \cdot \exp (-39700 / R T) \cdot a_{\mathrm{FeO}}
$$

(2) The chemical reaction rate equation at $1400^{\circ} \mathrm{C}$ expressed by $\mathrm{wt}^{\circ} \% \mathrm{FeO}$ instead of activity is

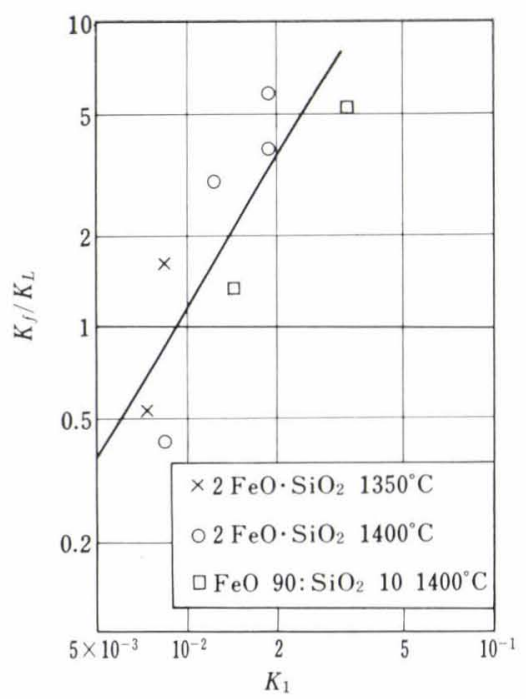

Fig. 8. Effect of bubbles on the laminar film shown as follows for the slag compositions indicated in paranthesis:

$$
\begin{aligned}
& \mathrm{FeO}-\mathrm{SiO}_{2} ; r=1.32 \times 10\left(\% \mathrm{FeO} \times 10^{-2}\right)^{3.79}, \\
& \mathrm{FeO}-\mathrm{SiO}_{2}-\mathrm{CaO}\left(\mathrm{SiO}_{2} / \mathrm{CaO}=11 / 9\right) ; \\
& \quad r=7.77 \times 10^{-2}\left(\% \mathrm{FeO} \times 10^{-2}\right)^{2.70}, \\
& \mathrm{FeO}-\mathrm{SiO}_{2}-\mathrm{MgO}\left(\mathrm{SiO}_{2} / \mathrm{MgO}=17 / 3\right) ; \\
& \quad r=2.063 \times 10^{-2}\left(\% \mathrm{FeO} \times 10^{-2}\right)^{2.14},
\end{aligned}
$$

and

$$
\begin{gathered}
\mathrm{FeO}-\mathrm{SiO}_{2}-\mathrm{Al}_{2} \mathrm{O}_{3}\left(\mathrm{SiO}_{2} / \mathrm{Al}_{2} \mathrm{O}_{3}=4 / 1\right) \\
r=1.11 \times 10^{-2}\left(\% \mathrm{FeO} \times 10^{-2}\right)^{1.07}
\end{gathered}
$$

(3) At lower rotation speed, the rate is considered to be controlled by both the diffusion in molten slags and the chemical reaction. Bubbles generated by reaction affect the diffusion in laminar film on a rod. According to the approximate calculation, the reaction surface seems covered by bubbles and the reaction rate decreases when the generation rate of bubbles is small. On the other hand in case of its fast generating rate, the bubbles break the laminar film on the rod and accelerate the reaction.

(4) Foaming in this experiment vigorously occurred in slags with high viscosity and surface tension, and their relationship was studied.

\section{Notation}

$A:$ surface area of reaction $\left(\mathrm{cm}^{2}\right)$

$a_{\mathrm{FeO}}:$ activity of $\mathrm{FeO}(-)$

$a_{\mathrm{FeO}}^{\prime}$ : value of activity of $\mathrm{FeO}$ at $1600^{\circ} \mathrm{C}$ obtained by Samarin and Shvartsman (-)

$C$ : mol concentration of $\mathrm{FeO}\left(\mathrm{mol} / \mathrm{cm}^{3}\right)$

$D$ : diffusion constant $\left(\mathrm{cm}^{2} / \mathrm{sec}\right)$

$d$ : rod diameter $(\mathrm{cm})$

$h$ : length of rod in a molten slag $(\mathrm{cm})$

$K$ : total mass transfer coefficient (cm/min)

$K_{1}$ : the first order reaction rate constant $(\mathrm{cm} /$ $\min$ )

$K_{2}$ : the second order reaction rate constant $\left(\mathrm{cm}^{4} / \mathrm{mol} \mathrm{FeO} \cdot \mathrm{min}\right)$

$K_{L}$ : mass transfer coefficient of rotation rod $(\mathrm{cm} / \mathrm{min})$

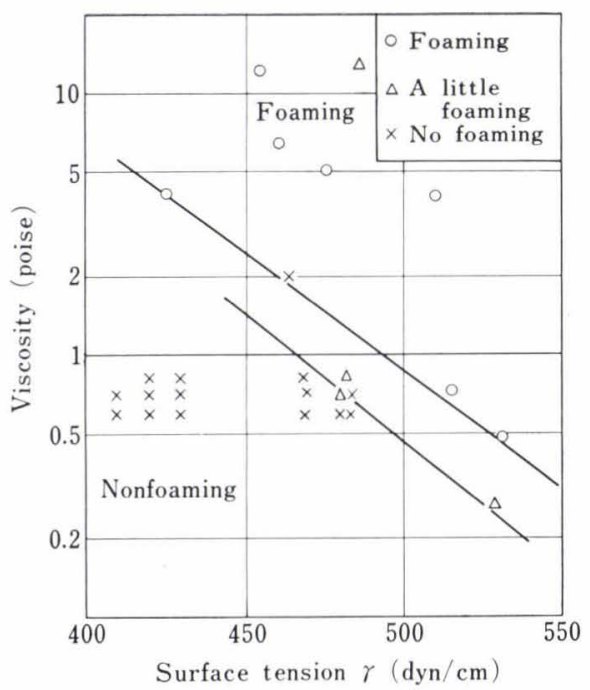

Fig. 9. Ranges of vigorous foaming and non-foaming under the $\mathrm{FeO}$ reduction experiment 


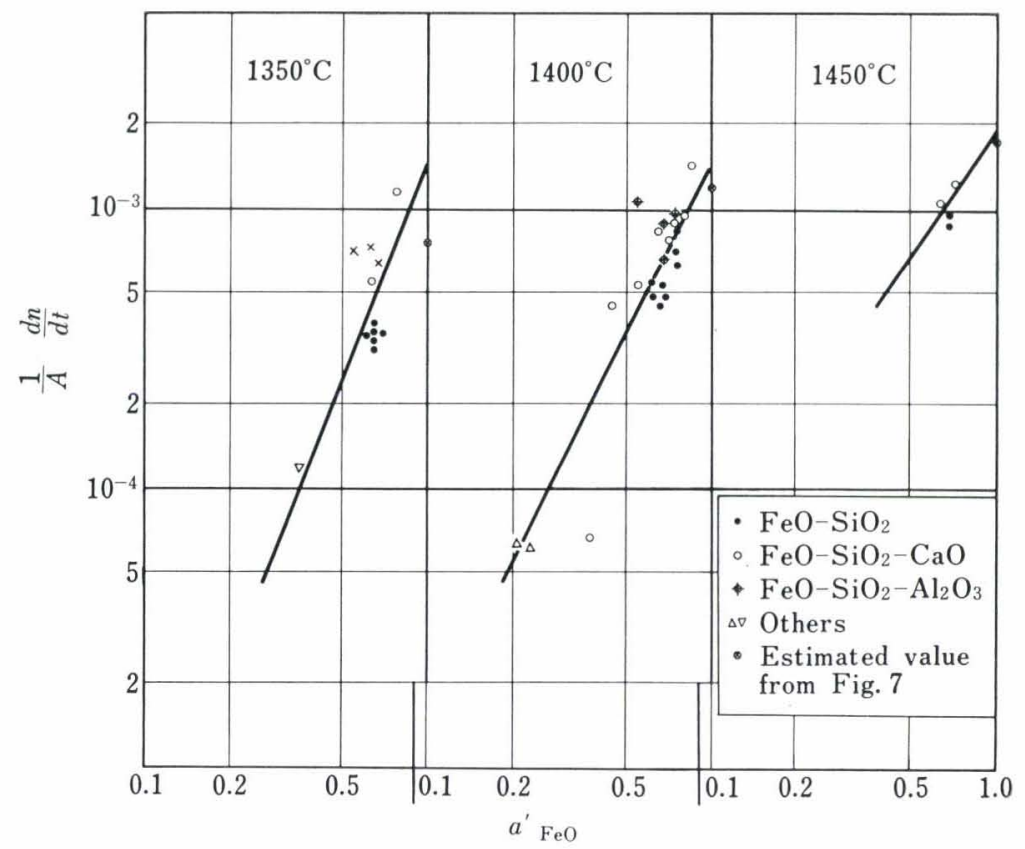

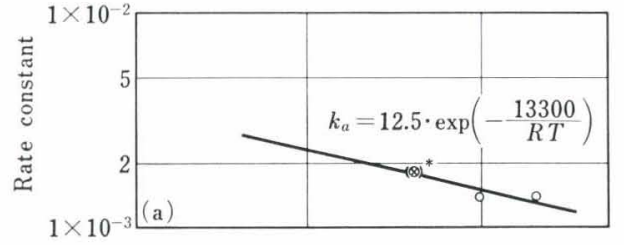

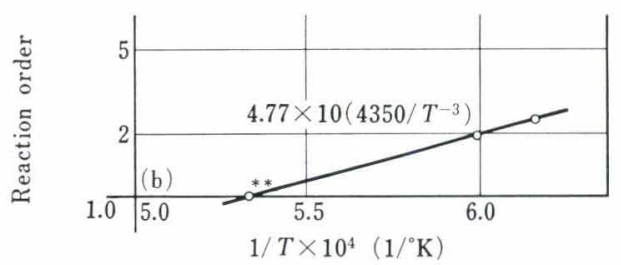

* Obtained from Fig. 7

** The value is obtained from the conclusion of Section III.2.2. that reaction is proportional to $\mathrm{FeO}$ activity at its temperature $1600^{\circ} \mathrm{C}$. The value at $1450^{\circ} \mathrm{C}$ is left out because of a few data.

Fig. 11. Relation between rate constant (a) and reaction order (b) of Fig. 8 and $1 / T$

Fig. 10. Differential plot of FeO reduction with $\mathrm{FeO}$ activity determined by Samarin et al.10,11) at $1600^{\circ} \mathrm{C}$

$K_{c}: \quad\left(=K_{1}\right)$

$K_{\mathrm{f}}$ : mass transfer coefficient $(\mathrm{cm} / \mathrm{min})$

M.Fe: weight fraction of metallic iron (-)

$\mathcal{N}$ : revolutional speed (r.p.m.)

$n_{\mathrm{FeO}}: \mathrm{FeO}$ mol number in liquid slag $(\mathrm{mol})$

$\dot{n}_{\mathrm{FeO}}$ : reaction rate $(\mathrm{mol} \mathrm{FeO} / \mathrm{min})$

$R: \quad$ gas constant $\left(\mathrm{cal} / \mathrm{mol} \cdot{ }^{\circ} \mathrm{K}\right)$

$R_{e}$ : Reynolds number (-)

$r$ : reaction rate $\left(\mathrm{mol} \mathrm{FeO} / \mathrm{cm}^{2} \cdot \mathrm{min}\right)$

$S_{c}$ : Schmidt number (-)

T: temperature $\left({ }^{\circ} \mathrm{K}\right)$

T.Fe: weight percent of total $\mathrm{Fe}(-)$

$t$ : time (min)

$V:$ volume of liquid slag $\left(\mathrm{cm}^{3}\right)$

$V_{1}$ : peripheral velocity of graphite rod

$W, W_{i}$ : weight of sample charged $(\mathrm{g})$

$\rho:$ density of liquid $\left(\mathrm{g} / \mathrm{cm}^{3}\right)$

$\mu$ : viscosity of liquid $(\mathrm{g} / \mathrm{cm} \cdot \mathrm{sec})$

$\nu$ : dynamic viscosity $\left(\mathrm{cm}^{2} / \mathrm{sec}\right)$

\section{Appendix: Derivation of a Pactical Equation}

From the result of the section III.2.2 the chemical reaction rate at various temperatures and slag systems can be obtained, if $\mathrm{FeO}$ activity is known. But it is difficult to make the rate equation at arbitrary temperature, because the activity diagrams are not easily available at the temperature. So $\mathrm{FeO}$ activity in a certain slag components is fixed regardless of the change of temperature. And such practical rate equation as its reaction constant and reaction order is changed with temperature, is made.

Some diagrams are published on $\mathrm{FeO}$ activity in multi-component slag. ${ }^{8,12-14)}$ In this report diagram at $1600^{\circ} \mathrm{C}$ by Samarin and Shvartsman ${ }^{10}$ and Matsushita $^{11)}$ was used, because it contained the most number of slag components, especially alumina. Relationship between chemical reaction rate and $\mathrm{FeO}$ activity is shown in Fig. 10. Also rate constant and reaction order against the reciprocal of temperature are plotted in Fig. 11 (a) and (b). The practical equation obtained from Figs. 10 and 11 is as follows:

$$
(-1 / A) \times \dot{n}_{\mathrm{FeO}}=12.5 \times \exp (-13300 / R T) \times\left(a_{\mathrm{FeO}}^{\prime}\right)^{m}
$$

where,

$$
\begin{aligned}
& m=4.76 \times 10^{(4350 / T-3)} \\
& a_{\mathrm{FeO}}^{\prime}: \text { FeO activity derived from Samarin's dia- } \\
& \text { gram at } 1600^{\circ} \mathrm{C} \text {. }
\end{aligned}
$$

Error of the reaction rate estimated from this equation, is within $50 \%$.

\section{REFERENCES}

1) K. Mori: The 54th Committee of Japan Society for the Promotion of Science No. 1072.

2) H. Krainer, H. P. Beer, and H. Brandi: Tech. Mitt. Krupp. Forsh. Ber., 24 (1966), 139.

3) W. O. Philbrook and L. D. Kirkbride: J. Metals, 8 (1965), 351.

4) S. V. Shabrin: Izv. VUZov, Cher. Met., (1964), No. 5, 7.

5) S. K. Tarby and W. O. Philbrook: Trans. Met. Soc. AIME, 239 (1967), 1005.

6) C. Bodsworth: JISI, 197 (1959), 13.

7) I. M. Davidson and C. Bodsworth: JISI, 198 (1960), 163.

8) E. T. Turkdogan and J. Pearson: JISI, 191 (1953), 217.

9) M. Eisenberg: CEP Symp. Ser., 51 (1955), 1.

10) K. Mori and K. Suzuki: Tetsu-to-Hagané, 54 (1968), 1199.

11) The Iron and Steel Institite of Japan: Yotetsu Yosai no Busseichi Binran, (1972), 40.

12) J. F. Elliott: J. Metals, 193 (1955), 485.

13) A. M. Samarin and L. A. Shvartsman: Izv. Akad., Nauk USSR, 12 (1949), 1639.

14) Y. Matsushita: Tetsu-to-Hagané, 37 (1951), 118. 